\title{
An old species and a new frontier: Some thoughts on the taxonomy of Homo erectus
}

\author{
Qian Wang, Phillip V. Tobias

\begin{abstract}
Sterkfontein Research Unit, School of Anatomical Sciences, University of the Witwatersrand, 7 York Rd., Parktown 2193, Johannesburg, South Africa E-mail: 055qwang@chiron.wits.ac.za
\end{abstract}

\begin{abstract}
The taxonomic impact on Homo erectus induced by a "preerectus-out-of-Africa" paradigm is preliminarily discussed in this article. Some of the early Homo species in Asia should be allocated to another taxon rather than to $H$. erectus, although their real identities are not yet readily apparent. Asian $H$. erectus may be taxonomically distinct from African $H$. ergaster. Differences between two samples of $H$. erectus from Java and China, suggesting taxonomic diversity or only geographical variances between these subsets, need further study. Reasons are advanced against the proposal to lump $H$. erectus into $H$. sapiens.
\end{abstract}

KEY WORDS genus Homo, Java, China, out-of-Africa

Prz. Antropol. - Anthropol. Rev. (2001), vol. 64, pp. 9-20, Figs. 4. ISBN 83-86969-644, ISSN 0033-2003

\section{Introduction}

There is growing evidence of human occupation, before $1 \mathrm{Ma}$ at some sites in Eurasia, such as Mojokerto and Sangiran in Java in Southeast Asia [SWISHER et al. 1994], Longgupo in East Asia [HUANG et al. 1995], Riwat and Pabbi Hills in central Asia [DENNELL et al. 1994; ALLCHIN 1995], Ubeidiya and Dmanisi in West Asia [BAR-YOSEF \& GOREN-INBAR 1993; GABUNIA et al. 2000], and probably Orce in Europe [GIBERT 1993; ROE 1995; TOBIAS 1998]. The antiquity of humankind out- side Africa has already been established. Recently, much has been written on the first Eurasian hominid inhabitants [WOOD \& TURNER 1995; CIOCHON 1995; LARICK \& CIOCHON 1996; HOU \& HuANG 1998; Clarke 2000; MANZI 2001; PERETTO 2001], and "a very early out-of-Africa scenario in which the first hominids left Africa about $2 \mathrm{Ma}$ has become a fashionable concept in palaeoanthropology" [LANGBROEK \& ROEBROEKS 2000].

Much mystery still envelops early hominid movements from Africa [MANZI 2001], such as the identity of 
the first emigrants, whether $H$. habilis or H. ergaster, or Homo unknown. Nevertheless the occurrence of such a "pre$H$. erectus" event would have a striking impact on ideas about $H$. erectus, since this new paradigm overturns the old "erectus-out-of-Africa" paradigm, which posited that $H$. erectus was the first hominid species to venture out of Africa, complete with Acheulean technology. This interpretation could be counted as a third major impact on the place of $H$. erectus in human evolution, following the loss of its "Missing Link" status in the 1950s after the wide recognition of the hominid character of Australopithecus, and the discrediting of its ancestral position to $H$. sapiens after the 1970s. Similarly, this shift places $H$. erectus, the old species, at a new frontier in paleoanthropology, for the removal of temporal uncertainty by newer dating methods has placed human evolutionary events outside of Africa at $2 \mathrm{Ma}$ and onwards. This necessitates a rethinking of the role of $H$. erectus in this new scenario. Therefore we endeavor in this article to offer a preliminary analysis of how the new paradigm will open a new vista in addressing $H$. erectus issues and how it will influence our thoughts on the taxonomy of H. erectus.

\section{Taxonomic emancipation of H. erectus}

One of the by-products of the "erectus-out-of Africa" paradigm has been an almost rigid rule that all pre$H$. sapiens hominid fossils in East and Southeast Asia be assigned to $H$. erectus. Thus some remains have been allocated to " $H$. erectus" largely or exclu- sively because of their dating and geographical settings, which inevitably has led to an uncomfortably high degree of variation of this hypodigm [TYLER 1992; ZEITOUN 2000].

It has long been suspected that some hominid forms more primitive or archaic than $H$. erectus existed in Asia, especially in Java, some comparable to $\mathrm{H}$. habilis, or even an earlier form [ROBINSON 1953; VON KOENIGSWALD 1954; TOBIAS \& VON KOENIGSWALD 1964; JACOB 1973; TYLER 1992]. The probable prolongation of human occupation of Asia opens the way to accommodate some samples different from typical $H$. erectus from Trinil and Sangiran, such as the so-called Meganthropus. Even though there is no convincing fossil evidence for the establishment of an African species, or exact dating results to connect these primitive forms with $H$. erectus time-successively, they are either early Homo prior to typical $H$. erectus or sympatric variants of the latter.

In China, there were similar claims too. Several teeth found at Jianshi, Hubei, were classified as Australopithecus [GAO 1975], but they were reclassified as $H$. erectus on the grounds that the teeth are Homo-like and comparable to habiline Meganthropus in Java [ZHANG 1984]. Their affiliation should be restudied under the new circumstances. Longgupo hominid remains, an isolated incisor and a fragmentary mandible, were originally assigned to $H$. erectus, doubtless under the influence of the "erectus-out-of-Africa" paradigm, while the site was then dated to around 2 Ma [HUANG \& FANG 1991]. The Longgupo remains were subsequently reinterpreted as early Homo [HUANG et al. 
1995]. However, due to the meager nature of these remains, their identity, as H. habilis [CIOCHON 1995], or H. ergaster [WOOD \& TURNER 1995], has not been fully resolved. Even though the antiquity of the incisor and the human assignment of the mandible are still in question [SCHWARTZ \& TATTERSALL 1996; WOLPOFF 1996; WANG 1996; WU 2000], the existence of stone stools confirms the existence of human activity at this site. The Longgupo industry, including pick, cleaver, chopper, Kombewa flake, is very comparable to East African Oldowan technology [HUANG 2000].

Chronologically the Dmanisi hominid (1.7 Ma) in Georgia may not represent the earliest humans outside Africa, but it might be very close in morphology to the earliest settlers who moved to East and Southeast Asia. It has been claimed that Dmanisi skulls were linked to $H$. ergaster in general cranial morphology, as represented by the remains of Koobi Fora in Kenya (ER 3733, ER 3883) [GABUNIA et al. 2000], but earlier, BRAUER \& SCHULTZ [1996] found the accompanying mandible to be of advanced $H$. erectus form. Upon checking the original description and the cast of one of the crania (D 2280) kindly provided by Dr Lordkipanidze, we were impressed that they differed from $H$. ergaster in their relatively lower cranial profile, heavily developed supraorbital torus, and some details in the frontal bones. On the contrary, their general cranial shape, proportion and calvarial size resemble those of $\mathrm{H}$. habilis and Asian typical $H$. erectus. The chronologically comparable Sangiran 31 cranium $(1.66 \mathrm{Ma})$ diverges from the Dmanisi crania, in bearing a very strongly developed occipital torus and very thick cranial bones, at least in the rear part of the skull, suggesting early humans in Java might have evolved rapidly by adapting to the local environment. The Dmanisi specimens were obviously among the most important discoveries in paleoanthropology of the 20th century. Their coming to light proves that the search for humans' past should not be confined to the traditional paleoanthropological countries. The Early Pleistocene deposits should be investigated across the vast Eurasian landmass to find the earliest settlers, establish their identity and throw light on the timing and whereabouts of origin of $H$. erectus.

Moreover, the "pre-erectus-out-ofAfrica" paradigm may help us to jump out of an "Afro-Asian quagmire". The previous "erectus-out-of-Africa" paradigm enticed people to connect Asian and African human remains at the $H$. erectus stage both taxonomically and phylogenetically. But this supposed link raised many debates among paleoanthropologists, without resolution in sight [ANDREWS 1984; BRAUER 1990, 1994; BRAUER \& MBUA 1992; RIGHTMIRE 1984, 1990, 1998; STRINGER 1984; WOOD 1991, 1994; WOOD \& RICHMOND 2000; ZEITOURN 2000]. Under the new scenario, the proposal to establish a taxon, $H$. ergaster, for African "erectus" assemblage is reasonable. $H$. ergaster may have neither taxonomic nor phylogenetic relationship to Asian "erectus" (typical H. erectus or $H$. erectus sensu stricto), except that they may share the same ancestor [WoOD 1991, 1994]. Then we would be able to shift the focus of work from painstaking seeking or disproving Afro- 
Asian connection to comparing the evolutionary patterns after $2 \mathrm{Ma}$ in Africa and Asia, which will be very conducive to our understanding of human evolution.

Even though the exact identity of these earlier human forms and the timing and places of origin of $H$. erectus cannot be established at this moment, at any rate the emancipation of $H$. erectus from the taxonomic burden of serving as a midden for diverse earlier hominid forms makes the consideration of this species easier. It makes it possible to ponder seriously some questions previously eclipsed by the overcrowdedness phenomenon, such as the differences between and within the two "typical" $H$. erectus samples of Java and China.

\section{Indonesian - Chinese link revisited}

Since the initial comparison between the Javan and Zhoukoudian specimens [VON KOENIGSWALD \& WEIDENREICH 1939], they have for long been regarded as representatives of $H$. erectus. They are more comparable to each other in general cranial morphology, such as the ectocranial superstructures and the thickness of cranial bones, than to any other forms found in Africa and Europe. However, differences in features in these two regions have been recognized by many scholars, which are generally explained as chronological and geographical intraspecific differences [WEIDENREICH 1943; COON 1962; HOWELLS 1980; JACOB 1981; TOBIAS 1995].

First, they differ in the shape of the supra-orbital torus (Javan specimens have straight slab-like tori, and very shallow and broad supra-orbital sulci), in shape and proportion of calvaria (Javan specimens have a very broad rear part, and a more clear parietal angulation, and are more trapezoid-like as seen from above and from the rear) [DONG 1989]. The facial skeletons are well represented by Sangiran 17 and Tangshan in Java and China respectively. Even though they share a general topographic pattern [WANG \& TOBIAS 2000], the Tangshan face (see Figure 1) is more like that of modern humans with relatively smaller malar bones and very well developed canine fossa. The Javan specimen also has a smaller endocranial capacity, which might be associated with chronological differences. However, if we calculate sexual dimorphism of endocranial capacity based on WOLPOFF'S [1996] figures (p. 458, Table 67), the sexual difference at Zhoukoudian is $11.7 \%\left(965 / 1078 \mathrm{~cm}^{3}\right)$, at Java $17.9 \%\left(875 / 1031 \mathrm{~cm}^{3}\right)$, the latter

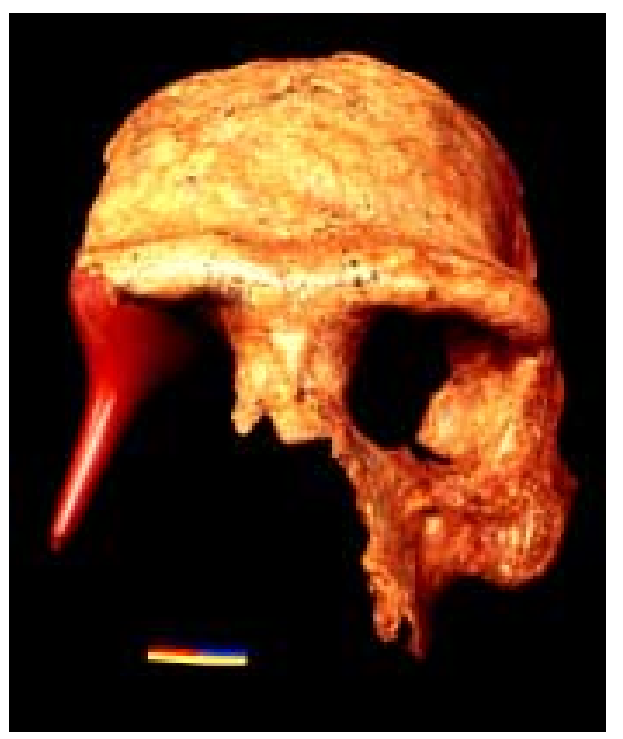

Fig. 1. Homo erectus skull from Tangshan (Nanjing) - Skull I (courtesy of Nanjing Municipal Museum). 
being closer to that of African $H$. erectuslike specimens, $17.6 \%\left(788 / 922 \mathrm{~cm}^{3}\right)$. An $H$. erectus tibial fragment from the Kabuh Formation at Sambungmacan, Java, has the thickened cortex and narrowed medullary cavity as in those at Zhoukoudian, whereas its triangular cross-section and transversely, somewhat flattened shape at mid-shaft show an external morphology pattern different from those of Zhoukoudian [MATSU'URA et al. 2000].

As for the Solo specimens, there are constant claims that they differ markedly from $H$. erectus in size and morphology. The shape and proportion of the Solo skulls are very different from Trinil and Sangiran crania, such as in the ratio of the minimum frontal breadth to the maximum neurocranial length, breadth and height, the Solo mean ratio being close to Early or Archaic H. sapiens in China, represented by Dali and Jinniushan, or to Euro-African H. heidelbergensis, represented by Petralona and Kabwe [WANG 1998].

Besides, if the surprisingly young dating (around $30 \mathrm{ka}$ ) for Solo remains is correct [SWISHER et al. 1996], Solo populations, whether of $H$. erectus [SANTA LUCA 1980; SWISHER et al. 1996], H. sapiens or $H$. heidelbergensis [ZEITOUN 2000], still lived in Java even after the appearance of modern humans in Africa, West and East Asia. Thus the evolutionary pattern could have been very different in Java from those in China and other parts of the Old World. Meantime, the spectrum of morphology variances became smaller in Indonesia, but bigger in China in the second half of the Late Middle Pleistocene [POPE 1994], as also did the cultural diversity [HUANG 2000].
Taken together, these differences would imply not only the independent acquisition of some endemic mode of skeletal adaptation by the early hominids in mainland Asia and insular Southeast Asia, but also possibly relatively independent evolution, especially in Java. Some scholars apply strict taxonomic practice and propose that typical $H$. erectus was endemic only to Java, or represented only by Trinil and Sangiran specimens [SCHWARTZ 2000; SCHWARTZ \& TATTERSALL 2000]. If this claim holds up, where would we place the Chinese remains? Does one revive "pekinensis" as a species name?

Curiously, the Hexian cranium from China (see Figure 2) shows a possible connection between the two samples, suggesting some evidence of gene flow between the two regions [WOLPOFF 1985; DONG 1989]. The Hexian cranium resembles "the Zhoukoudian remains in many details of the forehead profile as well as in the moderate frontal boss and the rounding of the superior orbital border" [WOLPOFF 1985]; and it resembles the Javan remains in the weak expression of the supratoral sulcus on the frontal and the general shape and proportion. Thus Hexian cranium looks like "a morphological as well as a geographical intermediary" [WOLPOFF 1985].

We do not propose to take the further step of suggesting the taxonomic splitting between Indonesian and Chinese $H$. erectus at this stage. They might be geographical variants adapted to tropical and sub-tropical zones respectively. Meantime, temporal and individual differences amplified their morphological distance. Therefore, the previous claim that they are two geographical subspecies may still hold [HowELLS 1980; 

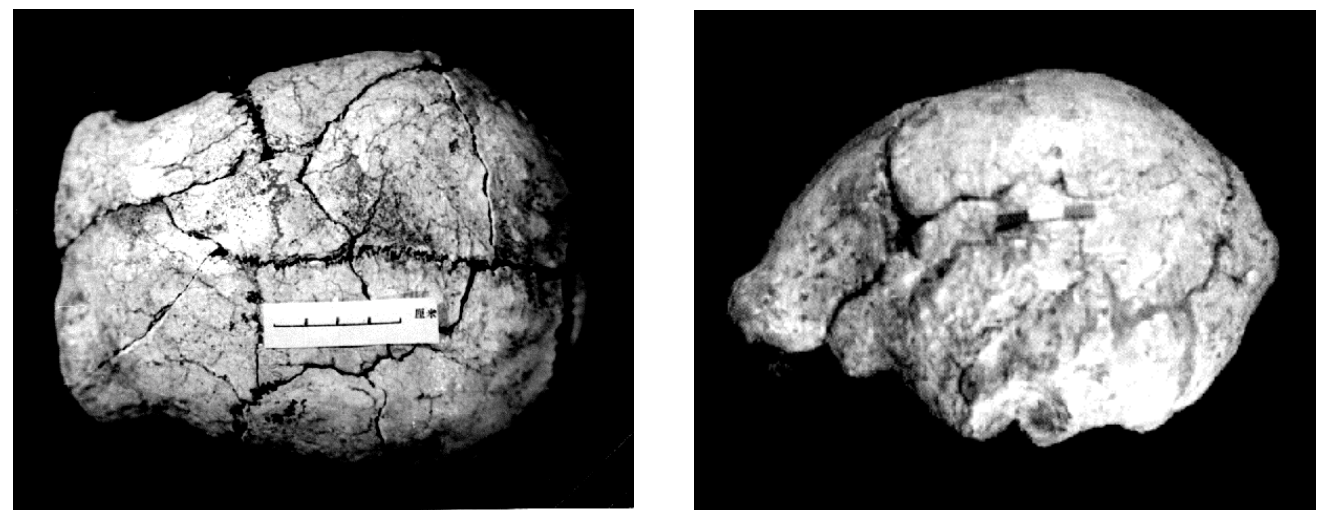

Fig. 2. Homo erectus calvaria (vertical and lateral view) from Hexian - PA 830 (courtesy of Wanpo Huang).

TOBIAS 1995]. If we take into account the situation of the unresolved problem of how to define "species" in biology and paleontology, we would like to take "typical" $H$. erectus as an assemblage, or form, with certain morphological indicators and within certain geographical and temporal contexts, just as RIGHTMIRE [1996] applied to $H$. heidelbergensis. Future finds of human fossils and cultural remains in China and Indonesia, and the region between, as well as more accurate dates, will be helpful in resolving the taxonomy of "erectus" forms, and their links to earlier and later hominids.

\section{An elusive species contempora- neous to $H$. erectus in China}

The debate on the affinities of Yuanxian skulls (Figs. 3 and 4) raised the possibility of the existence of another species during the time of $H$. erectus in China. Originally assigned to H. erectus [LI \& ETLER 1992], these skulls have some features usually seen in $H$. erectus, such as a very distinct postorbital constriction and the low po- sition of the maximum breadth of the brain case. However, other features are concordant with archaic Chinese $\mathrm{H}$. sapiens, such as thin cranial bones, very weak development of the angular torus in the inferoposterior angle of the parietal bones. The advanced features favor attribution to $H$. sapiens [WU \& POIRIER 1995], and there were attempts to put it with Dali, Jinniushan [ZHANG 1995], or with Arago and Petralona, implying its $H$. heidelbergensis status [CLARK et al. 1994].

However, the recent dates of Yunxian skulls are very intriguing. The associated fauna is comparable to that in Gongwangling, Lantian [LI et al. 1999], the latter being dated to about $1.15 \mathrm{Ma}$ by palaeomagnetism determinations [AN et al. 1990]. If such apparent incongruity in temporal framework is not induced by erroneous dating, for example human fossils being intrusive to the old fauna (this point needs careful taphonomic studies), then the scenario of human evolution in China should differ from what was previously thought. It opens again the possibility that archaic $H$. sapiens appeared around $1 \mathrm{Ma}$ 


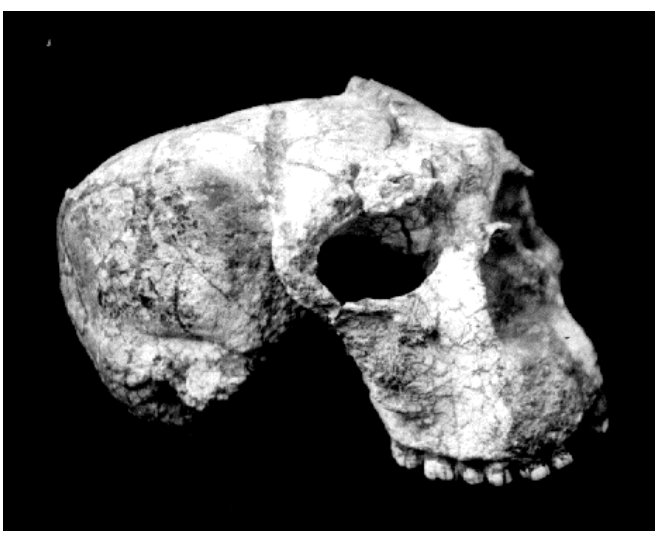

Fig. 3. Homo erectus skull from Yunxian (Quyuanhekou) - EV 9002 (courtesy of Tianyuan Li).

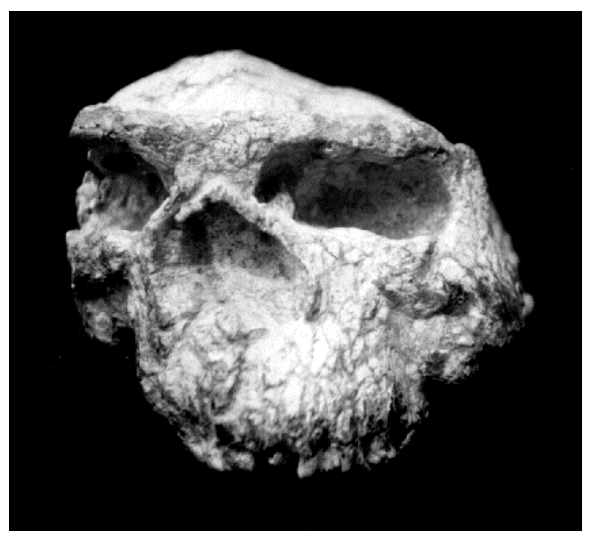

Fig. 4. Homo erectus skull from Yunxian (Quyuanhekou) - EV 9001 (courtesy of Tianyuan Li).
[ABBATE et al. 1998]. If it is the case, did Yunxian skulls belong to an advanced form, early $H$. sapiens and did a sympatric variation diverge from $H$. erectus at Gongwangling and Zhoukoudian, or did an eastward migration type such as $H$. heidelbergensis appear?

Moreover, there might have been at least two different evolutionary patterns in China. With its advanced features, Yunxian looks more likely to have represented the ancestral form, which eventually evolved into $H$. sapiens, while $H$. erectus might have become extinct without issue, as the "recent-outof-Africa" theory of origins of modern humans posits. However, the Zhoukoudian samples were dated to about 800-400 ka, predating early H. sapiens samples in China and chronologically possibly being an ancestral form [SHEN \& JIN 1991; SHEN et al. 2002]. Moreover, the facial morphology of the Tangshan skull reinforced the skeletal link between $H$. erectus with modern humans [WANG \& TOBIAS 2000]. However, this point would be very speculative in view of the Yunxian date based on faunal correlation. We propose that careful taphonomic study and dating analysis should be conducted before further interpretation is made. Meanwhile, it is worthy of note that the distortion of Yunxian crania has prevented an accurate assessment of their original forms. Thus the possible species contemporaneous with $H$. erectus in China remains elusive.

\section{H. erectus "into-Africa"?}

The taxonomic splitting of African "erectus" does not connote the dismissal of the possibility that $H$. erectus existed in Africa. Some fossils such as $\mathrm{OH} 9$ and Ndutu, are still possible $H$. erectus elements (e.g., WoOD [1994]). With the establishment of the "pre-erectus-out-ofAfrica" paradigm, some scholars propose that even though $H$. erectus was not the first hominid to venture out of Africa, it might have been the first human species to go back to Africa! [SWISHER et al. 1994; WOOD \& TURNER 1995; LARICK \& CIOCHON 1996; ClARKE 2000; MANZI 2001]. 
Although its development of ectocranial strengthening structures and cranial thickening and endocranial capacity are comparable to those of Asian $H$. erectus, $\mathrm{OH} 9$ differs from Asian $H$. erectus in some details. For instance, its supraorbital torus is the relatively most developed among human fossils, differing in size and shape from Asian remains. The degree of post-orbital constriction $(55.7 \%)$ is close to that of Australopithecus. Moreover, the angle formed by the supraorbital torus of two sides is about $153^{\circ}$, falling below the range for flat-faced $H$. erectus in Asia $\left(162-180^{\circ}\right)$ and within, but near the top of, the range for Euro-African $H$. heidelbergensis with protruding central face $\left(135-157^{\circ}\right)$. This may indicate that the $\mathrm{OH} 9$ face was less flat than in Asian $H$. erectus [WANG 1998]. Thus the affinity of $\mathrm{OH} 9$ to Asian $H$. erectus is not well proved.

On the contrary, the Ndutu skull is comparable to Asian $H$. erectus in similar cranial morphology such as the development of the supraorbital torus and of the angular torus. It also has an Inca bone-like intersutural bone at the lambdoidal region, which is a common feature of Chinese fossil hominids [WU \& POIRIER 1995]. Its facial topography resembles those of Asian $H$. erectus but differs from contemporaneous African $H$. heidelbergensis (Bodo and Kabwe) [WANG \& TOBIAS 2000]. Therefore, the Ndutu skull reveals the possibility of the extension of some Asian features into Africa in the Middle Pleistocene, probably through input by $H$. erectus.

"Into Africa" is not an uncommon paleontological phenomenon. From the Mesozoic, the Eurasian mammalian record began to appear in Africa, and from then on a close faunal link between Africa and northern Eurasia was established [MAGLIO 1978; KINGDON 1993]. After $2 \mathrm{Ma}$, Africa is no longer the only continent supporting hominid inhabitants. Eurasia provided sites of origin of certain species, such as $H$. erectus and the Neandertals, and probably the source of human movements too. The Neandertals might have originated in Europe and then moved eastward into west and central Asia. H. erectus might have appeared first in East Asia, and moved westward to Europe (Ceprano) [ASCENZI et al. 1996], and to Africa (Ndutu). The eastward and westward movements apparently promoted the genetic and cultural links between different paleoanthropological provinces, which would be conducive to the making of humankind.

\section{A case against lumping $H$. erectus into $H$. sapiens}

Given such alterations or uncertainties of " $H$. erectus" discussed above, at the moment it is recommended that $H$. erectus be not lumped into $H$. sapiens, an issue much discussed during the last decade [WOLPOFF et al. 1994; TOBIAS 1995; WOLPOFF 1996].

First, the previous Afro-Asian " $H$. erectus" might consist of multiple types in different regions. Different geographical variants of " $H$. erectus" show different evolutionary trends, for instance at least two in facial morphology evolution [WANG \& TOBIAS 2000], so the lumping of those variants would obscure this phenomenon, and invite confusion. Secondly, there is perceptible morphological distance in cranial morphology [WU \& WU 1982; WANG 1998; 
WANG \& TOBIAS 2000; ZEITOUN 2000]. They appear to represent different evolutionary stages. Thirdly, the Asian and Australasian continuity in human evolution is more or less an established skeletal story. But genetic findings tend to deny the ancestral status of " $H$. erectus" [STRINGER \& ANDREWS 1989]. That the relationship between " $H$. erectus" and $H$. sapiens in the above-mentioned regions is ancestor-descendant, or is only successive in time, still awaits further reconciliation among different lines of evidence.

Even though "lumping" seems not to be "a harmless endeavor", it does not facilitate discussion, and may bring oversimplification to the process of addressing human evolution during the past $2 \mathrm{Ma}$, especially of a species, or an assemblage, we suddenly feel we know so incompletely under the new circumstances.

The satisfactory solution of the taxonomy of $H$. erectus will require knowledge and techniques from many fields, the insight of paleoanthropologists, skeletal and forensic biologists, and molecular biologists, chronologists, paleolithic archaeologists, paleontologists and so on. If the tempo of development of paleoanthropology and its cognate disciplines over the last two decades is maintained or even accelerated in the coming years, we could come much closer to the reality of this old but very fascinating species.

\section{Acknowledgements}

QW thanks the National Research Foundation of South Africa and the University of the Witwatersrand for financial support. PVT is grateful to the
PAST Fund, the Department of Arts, Culture, Science and Technology of the South African Government. We also thank the School of Anatomical Sciences, University of the Witwatersrand, Johannesburg; Institute of Vertebrate Paleonthology and Paleoanthropology, Beijing; Nanjing Municipal Museum, Nanjing; as well as Prof. Tianyuan Li, Prof. Wanpo Huang, Dr David Lordkipanidze, Dr Katarzyna A. Kaszycka, Mr. Anthony D.T. Kegley, Mrs. Heather White and Ms. Li Sun.

\section{References}

Abbate E., A. Albianelli, A. Azzaroli, M. BENVENUTI, et al., 1998, A one-million-yearold Homo cranium from the Danakil (Afar) depression of Eritrea, Nature, 393, 458-460

Allchin B., 1995, The Potwar Project 1981 to 1993: A concluding report on the British Archaeological Mission to Parkistan's investigations into hominid and early human cultures and environments in the Northern Punjab, Pakistan, South Asian Studies, 11, 149-156

AN Z., W. GAO, Y. ZHU, X. KAN, J. WANG, J. SUN, M. WEI, 1990, Magnetostratigraphic dates of Lantian Homo erectus, Acta Anthropol. Sin., 9, 1-7

ANDREWS P.A., 1984, An alternative interpretation of the characters used to define Homo erectus, Cour. Forsch.-Inst. Senckenb., 69, 167-175

Ascenzi A., I. Biddittu, P.F. CAssoli, A. Segre, F. Segre-Naldini, 1996, A calvarium of late Homo erectus from Ceprano, Italy, J. Hum. Evol., 31, 409-423

BAR-Yosef O., N. GOREN-IMBAR, 1993, The lithic assemblages of Ubeidiya. A Lower Palaeolithic site in the Jordan Valley, Jerusalem, The Hebrew University of Jerusalem

BRAUER G., 1990, The occurrence of some controversial Homo erectus cranial features in the Zhoukoudian and East African hominids, Acta Anthropol. Sin., 9, 352-358

Brauer G., 1994, How different are Asian and African Homo erectus? Cour. Forsch.-Inst. Senckenb., 171, 301-318 
Brauer G., E. MBuA, 1992, Homo erectus features used in cladistics and their variability in Asian and African hominids, J. Hum. Evol., 22, 78-108

Brauer G., M. Schultz, 1996, The morphological affinities of the Plio-Pleistocene mandible from Dmanisi, Georgia, J. Hum. Evol., 30, 445-481

Ciochon R., 1995, The earliest Asians yet, Nat. Hist., 104, 50-54

Clark J.D., J. DE Heinzelin, K.D. Schick, W.K. HART, et al., 1994, African Homo erectus: old radiometric ages and young Oldowan assemblage in the Middle Awash Valley, Ethiopia, Science, 264, 1907-1910

ClARKE R.J., 2000, Out of Africa and back again, Int. J. Anthropol., 15, 185-189

Coon C.S., 1962, The origin of races, A. Knopf, New York

Dennell R.W., H.M. Rendell, L. Hurcombe, E.A. HAILWOOD, 1994, Archaeological evidence for hominids in Northern Pakistan before one million years ago, Cour. Forsch. -Inst. Senckenb., 171, 151-155

Dong X., 1989, Homo erectus in China, [in:] Early Humankind in China, R. Wu, X. Wu \& S. Zhang (eds.), Science Press, Beijing, pp. 9-23

Gabunia L., A. VeKuA, D. LordKipanidze, C.C. SWISHER, et al., 2000, Earliest Pleistocene hominid cranial remains from Dmanisi, Republic of Georgia: taxonomy, geological setting, and age, Science, 288, 1019-1025

GAO J., 1975, Australopithecine teeth associated with Gigantopithecus, Vertebrata PalAsiatica, 13, $81-88$

Gibert J. (ed.), 1993, Proyecto Orce-Cueva Victoria (1988-1992): Presencia Humanaen el Pleistoceno Inferior de Granada y Murcia, Orce, Granada, Museo de Prehistoria Josep Gibert

Hou Y., W. HuAng, 1998, East Asia and the first migration tide of early man, Acta Anthropol. Sin., 17, 293-309

Howells W.W., 1980, Homo erectus - who, when and where: a survey, Yrbk Phys. Anthropol., 23, 1-23

HuAng W., 2000, Greeting Chinese Paleolithic Archaeology in the $21^{\text {st }}$ Century (a retrospective), Acta Anthropol. Sin., 19 (suppl.), 104-114

Huang W., R. Ciochon, Y. Gu, R. LARick, et al., 1995, Early Homo and associated artefacts from Asia, Nature, 378, 275-278
HuANG W., Q. FANG (eds.), 1991, Wushan hominid site, Beijing, Ocean Press

JАCOB T., 1973, Paleoanthropological discoveries in Indonesia with special references to the finds of the last two decades, J. Hum. Evol., 2, 473-486

JАCOB T., 1981, Solo man and Peking man, [in:] Homo erectus - Papers in honor of Davidson Black, B.A. Sigmon \& J.S. Cybulski (eds.), University of Toronto Press, Toronto, pp. 87104

KINGDON J., 1993, Self-made man: human evolution from Eden to extinction? John Wiley \& Sons, New York

Koenigswald G.H.R. von, 1954, The Australopithinae and Pithecanthropus, Proc. Kon. Nederl. Akad., 57, 85-91

KoEnigswald G.H.R. VON, F. WeIDENREICH, 1939, The relationship between Pithecanthropus and Sinanthropus, Nature, 144, 926-929

LANGBROEK M., W. ROEBROEKS, 2001, Extraterrestrial evidence on the age of the hominids from Java, J. Hum. Evol., 38, 595-600

LARICK R., R.L. CIOCHON, 1996, The African emergence and early Asian dispersals of the genus Homo, Am. Sci., 84, 538-551

Li P., F. QIAN, X. MA, L. XiNG, S. JU, 1976, A preliminary study of the age of Yuanmou man by paleomagnetic techniques, Scientia Sinica, 6, 579-591

Li T., D.A. EtLer, 1992, New Middle Pleistocene hominid crania from Yunxian in China, Nature, 357, 404-407

Li T., W. Li, X. Feng, X. Wu, 1999, Discovery and study of Yunxian hominid site, Longgupo Historic Culture, 1, 81-103

Maglio V.J., 1978, Patterns of faunal evolution, [in:] Evolution of African mammals, V.J. Maglio \& H.B.S. Cooke (eds.), Harvard University Press, Cambridge, pp. 603-619

Matsu'ura S., M. Kondo, F. Aziz, SudiJono, S. NARASAKI, N. WATANABE, 2000, First known tibia of an early Javanese hominid, Curr. Anthropol., 41, 297-300

MANZI G., 2001, The earliest diffusion of the genus Homo toward Asia and Europe: a brief overview, [in:] Humanity from African naissance to coming millennia, P.V. Tobias, M.A. Raath, J. Moggi-Cecchi \& G. Doyle (eds.), Firenze University Press, Firenze; Witwatersrand University Press, Johannesburg, pp. 117-124 
Peretto C., 2001, The oldest human population in Europe: "long" or "short" chronologies. [in:] Humanity from African naissance to coming millennia, P.V. Tobias, M.A. Raath, J. Moggi-Cecchi \& G. Doyle (eds.), Firenze University Press, Firenze; Witwatersrand University Press, Johannesburg, pp. 175-180

Pope G.G., 1994, An historical and scientific perspective on paleoanthropological research in the East, Cour. Forsch.-Inst. Senckenb., 171, 23-32

RightmiRe G.P., 1984, Comparison of Homo erectus from Africa and Southeast Asia, Cour. Forsch.-Inst. Senckenb., 69, 83-98

RightMiRe G.P., 1990, The evolution of Homo erectus: comparative anatomical studies of an extinct human species, Cambridge University Press, Cambridge

RightMiRE G.P., 1996, The human cranium from Bodo, Ethiopia: evidence for speciation in the Middle Pleistocene? J. Hum. Evol., 31, 21-39

RigHTMIRE G.P., 1998, Evidence from facial morphology for similarity of Asian and African representatives of Homo erectus, Am. J. Phys. Anthropol., 106, 61-85

RoBINSON J.T., 1953, Meganthropus, australopithecines and hominids, Am. J. Phys. Anthropol., 11, 1-38

RoE D.A., 1995, The Orce basin (Andalucia, Spain) and the initial palaeolithic of Europe, Oxford J. Archaeol., 14, 1-12

SANTA LuCA A.P., 1980, The Ngangdong fossil hominids - A comparative study of a Far Eastern Homo erectus group, Publ. Anthropol., Yale University, 78, 1-175

SChWARTZ J.H., 2000, Taxonomy of the Dmanisi crania, Science, 289, 55-56

Schwartz J.H., I. TATTERSALl, 1996, Whose teeth? Nature, 381, 200-201

SCHWARTZ J.H., I. TATTERSALl, 2000, What constitutes Homo erectus? Acta Anthropol. Sin., 19 (suppl.), 18-22

SHEN G., L. JIN, 1991, Restudy of the upper age limit of Beijing Man cave, Acta Anthropol. Sin., 10, 273-277

Shen G., T-L. Ku, H. Cheng, R.L. Edwards, Z. YUAN, Q. WANG, 2002, High-precision $U$-series dating of Locality 1 at Zhoukoudian, China, J. Hum. Evol., (in press)

StRINGER C.B., 1984, The definition of Homo erectus and the existence of the species in Africa and Europe, Cour. Forsch.-Inst. Senckenb., 69, 131-143
Stringer C.B., P. ANDREWs, 1988, Genetic and fossil evidence for the origin of modern humans, Science, 239, 1263-1268

Swisher C.C., G.H. Curtis, T. Jacob, A.G. GetTy, A. Supprijo, Widiasmoro, 1994, Age of earliest known hominids in Java, Indonesia, Science, 263, 1118-1121

Swisher C.C., J. RinK, S.C. ANTON, H.P. Schwarcz, G.H. Curtis, A. Supprijo, WidiasMORO, 1996, Latest Homo erectus of Java: Potential contemporaneity with Homo sapiens in Southeast Asia, Science, 274, 1870-1874

TOBIAS P.V., 1995, Thoughts on Homo erectus and its place in human evolution, Acta Anthropol. Sin., 14, 297-312

TOBIAS P.V., 1998, Some comments on the case for Early Pleistocene hominids in SouthEastern Spain, Hum. Evol., 13, 91-96

Tobias P.V., G.H.R. von Koenigswald, 1964, A comparison between the Olduvai hominines and those of Java and some implications for hominid phylogeny, Nature, 204, 515-518

TYLER D.E., 1992, A taxonomy of Javan hominid mandibles, Acta Anthropol. Sin., 11, 285-299

WANG Q., 1996, Assignment of Longgupo Cave hominid incisor from Wushan, Acta Anthropol. Sin., 15, 320-323

WANG Q., 1998, Comparison between AfroEuropean Homo heidelbergensis and Chinese Homo erectus, Ph.D. Thesis, Institute of Vertebrate Paleontology and Paleoanthropology, Academia Sinica, Beijing

WANG Q., P.V. ToBias , 2000, Review of the phylogenetic position of Chinese Homo erectus in light of midfacial morphology, Acta Anthropol. Sin., 19 (suppl.), 23-33

WEIDENREICH F., 1943, The skull of Sinanthropus pekinensis : a comparative study on a primitive hominid skull, Palaeontol. Sin., N.S. D, 10

WOLPOFF M.H., 1985, Human evolution at the peripheries: the pattern at the eastern edge, [in:] Hominid evolution - past, present and future, P.V. Tobias (ed.), Alan R. Liss, New York, pp. 335-365

WOLPOFF, M.H., 1996, Human Evolution (19961997 edition), McGraw- Hill Co., New York

WOLPOFF M.H., A.G. ThORNE, J. JELINEK, Y. ZHANG, 1994, The case for sinking Homo erectus. 100 years of Pithecanthropus is enough! Cour. Forsch.-Inst. Senckenb., 171, 341-361

Wood B., 1991, Koobi Fora research Project, 4: Hominid cranial remains, Clarendon Press, Oxford 
WooD B., 1994, Taxonomy and evolutionary relationships of Homo erectus, Cour. Forsch.Inst. Senckenb., 171, 159-165

WoOD B., B.G. RICHMOND, 2000, Human evolution: taxonomy and paleobiology, J. Anat., 196, 19-60

Wood B., A. Turner, 1995, Out of Asia and into Asia, Nature, 378, 339-340

Wu R., X. WU, 1982, Comparison of Tautavel man with Homo erectus and early Homo sapiens in China, [in:] Proceedings of the ler Congrès International de Paleontologie $\mathrm{Hu}$ maine, Nice, pp. 605-616

Wu X., 2000, Longgupo hominoid mandible belongs to ape, Acta Anthropol. Sin., 19, 1-10
Wu X., F.E. PoIRIER, 1995, Human evolution in China: a metric description of the fossils and a review of the sites, Oxford University Press, New York

Zeitoun V., 2000, Revision de l'espèce Homo erectus (Dubois, 1893), Bulletins et Memoires de la Societé d'Anthropologie de Paris, Nouvelle Serie, 12, 1-200

ZHANG Y., 1984, The "Australopithecus" of West Hubei and some early Pleistocene hominids of Indonesia, Acta Anthropol. Sin., 3, 85-92

ZHANG Y., 1995, Human fossil crania from Yunxian: morphological comparison with Homo erectus crania from Zhoukoudian, Acta Anthropol. Sin., 14, 1-7

\section{Streszczenie}

Gwałtowny rozwój paleoantropologii i pokrewnych jej dyscyplin, jaki nastąpił w ciągu ostatniej dekady, poważnie zmienił poglądy specjalistów na ewolucję człowieka i stworzył nową perspektywę dla badań ludzkiej przeszłości. Ustanowienie nowego paradygmatu ,,preerectus-out-of-Africa", przypisującego formom pre-erectus ekspansję z Afryki do Eurazji, spowodowało, że badaniami wydarzeń związanych z ewolucją człowieka poza kontynentem afrykańskim należało objąć okres $2 \mathrm{mln}$ lat. Zmusza to do ponownego przemyślenia roli Homo erectus w tym nowym scenariuszu.

W przedstawianym artykule staramy się zaproponować, jak zgodnie ze wspomnianym paradygmatem winien zmienić się także pogląd na taksonomię $H$. erectus. Przede wszystkim, rozpoznanie wczesnych form rodzaju Homo, poprzedzających $H$. erectus (nawet jeśli ich ostatecznej tożsamości nie można jeszcze ustalić), uwalnia takson $H$. erectus od niewdzięcznej roli „taksonomicznego śmietnika” wszystkich wczesnych form hominidalnych. Po drugie, dalszych studiów wymaga zróżnicowanie przedstawicieli H. erectus z Chin i z Jawy; różnice te mogą być interpretowane jako wynik dywergencji taksonomicznej, lub jedynie geograficznego zróżnicowania w obrębie gatunku. Po trzecie, nie widzimy ani taksonomicznych, ani filogenetycznych powiązań między afrykańskim $H$. ergaster i azjatyckim $H$. erectus. Czaszka z Ndutu (Tanzania), jakkolwiek takie nawiązania wykazuje, sugeruje możliwość przeniknięcia pewnych cech (pochodzących zapewne od azjatyckiego $H$. erectus) z Azji do Afryki w środkowym plejstocenie. Po czwarte wreszcie, uważamy, że nie należy włączać $H$. erectus do taksonu $H$. sapiens, ponieważ mogłoby to nadmiernie upraszczać interpretację procesu ewolucji człowieka w ciągu ostatnich 2 mln lat, a szczególnie ewolucji azjatyckich form, o których - jak się nagle okazało - nasza wiedza ciągle jeszcze jest zbyt niekompletna. 